\title{
The environmental requirements of Crunoecia irrorata (Curtis, 1834) (Trichoptera: Lepidostomatidae) and the potential of the species for use as an indicator: an example from the Vistulian glaciation area
}

\author{
Anna RYCHŁA,${ }^{1 *}$ Edyta BUCZYŃSKA,${ }^{2}$ Anna Maria SZCZUCIŃSKA ${ }^{3}$ \\ ${ }^{1}$ Society for Lubusz Cultural Landscape, Sucharskiego 28/9, 65-562 Zielona Góra, Poland; ${ }^{2}$ Department of Zoology, Animal Ecology \\ and Wildlife Management, University of Life Sciences, Akademicka 13, 20-033 Lublin, Poland; ${ }^{3}$ Institute of Physical Geography and \\ Environmental Planning, Adam Mickiewicz University, Dzięgielowa 27, 61-680 Poznań, Poland \\ *Corresponding author: an.rychla@gmail.com
}

\begin{abstract}
The caddisfly Crunoecia irrorata is a wide-spread species in Europe and inhabits permanent spring areas with pristine or moderately disturbed habitat conditions. However, the pattern of its distribution on the national scale as well as detailed preferences toward water properties are still insufficiently known. To complete this knowledge we analysed at first the distribution of this species in Poland which showed that its extent involves the whole territory, however, with sparse occurrence in most regions and with large areas where the species has not been observed yet. The data compilation also showed that the species'frequency of occurrence is highest in the central-western region of Poland. Furthermore, its frequency of occurrence decreased towards the east and the northeast. Because the highest frequency of occurrence of this species was found in central-western Poland, the spring sites in this region were used as a model area for the analysis of the hydrochemical conditions associated with the species (25 parameters). The results of the study showed that $\mathrm{C}$. irrorata strongly prefers habitats with low nitrate $\left(\mathrm{NO}_{3}\right)$ and chloride $(\mathrm{Cl})$ concentrations. In detail, a regression model showed that the probability of occurrence of $\mathrm{C}$. irrorata was only $5 \%$ at concentrations of $32 \mathrm{mg} \mathrm{L}^{-1} \mathrm{NO}_{3}$ and $35 \mathrm{mg} \mathrm{L}^{-1} \mathrm{Cl}$. In contrast, high concentrations of heavy metals (zinc, lead, cooper, chromium, and cadmium) as well as of total iron and manganese did not significantly influence the presence of this species. In conclusion, environmental assessments relating to human health and landscape health can use C. irrorata as an indicator species for biogenic and salt pollution, but the species is not a potential indicator of heavy metals in spring water. Therefore, information on the presence of $\mathrm{C}$. irrorata can serve to preserve crenic ecosystems and their assemblages and can be used to prevent anthropogenic contamination of these ecosystems.
\end{abstract}

Key words: Caddisflies, springs, species distribution, pollution, nitrate, chloride.

Received: September 2014. Accepted: January 2015.

\section{INTRODUCTION}

Crunoecia irrorata (Curtis, 1834) (Trichoptera: Lepidostomatidae) is classified as a rare species at the European scale (Graf et al., 2006, 2008; Graf and Schmidt-Kloiber, 2011) and is the only caddisfly species legally protected in Poland (Ministerstwo Środowiska, 2014). The species is stenotopic and occurs primarily in lowland and upland springs across Europe (Graf et al., 2008; Graf and Schmidt-Kloiber, 2011). Its marked habitat restriction and a characteristic tetrahedral case allow simple identification, thus making it an excellent candidate for an umbrella species (cover species) to protect crenic ecosystems and their assemblages (Czachorowski et al., 2000a). It has been shown that $C$. irrorata is strongly associated with natural and near-natural springs (Schindler, 2004; Martin and Brunke, 2012), thus serving as an indicator of nearly undisturbed habitat conditions. Additionally, a higher species richness, as well as a higher number of red-listed species, have been reported from springs occupied by $C$. irrorata compared with springs without this species (Buczyńska, 2008; Ilmonen, 2008). This information also suggests the great potential of this species in terms of the conservation of the co-occurring rare crenic specialists. However, knowledge of the distribution of C. irrorata in Poland is still scattered and incomplete. Since the species has been protected in Poland, no comprehensive work summarising the current distribution and habitat preferences of $C$. irrorata has appeared. The only summary of the distribution of caddisfly species in Poland was furnished almost 50 years ago by Tomaszewski (1965). Although there are many records for $C$. irrorata in the recent literature, primarily as a result of faunistic studies, it is extremely difficult to note either hot spots or areas lacking information about this species. Consequently, it is difficult to evaluate conservation strategies for C. irrorata and to effectively preserve the habitats in which this species resides.

Undisturbed springs are considered to represent sources of high-quality water (Galas, 2005). For this reason, they have an important function for humans as a 
source of drinking water (Chelmicki et al., 2011). Simultaneously, they are also characterised by a low level of temporal variability of hydrological and hydrochemical conditions compared with other freshwater sources. Thus, the species inhabiting spring ecosystems are often strictly associated with these ecosystems (Glazier, 1991; Hahn, 2000; Schindler, 2004; Gerecke et al., 2009; Cantonati et al., 2012). Many previous investigations have documented more or less strong relationships between various environmental components and the composition and/or diversity of crenic assemblages (Schindler, 2004; Barquín and Death, 2009; Ilmonen et al., 2012). However, considerably less information on the tolerance of individual species to particular water characteristics is currently available (Bonada et al., 2004; Qu et al., 2010), although the available information allows the determination of indicator species for specific pollutants in aquatic habitats and, additionally, for the assessment of water quality (Bonada et al., 2004). However, knowledge of the ecological requirements of individual species is an important tool in management and in strategies of biodiversity conservation, especially for predicting optimal conditions for rare species.

The main goal of the present study was to analyse the state of knowledge of the distribution of $C$. irrorata in Poland, based on a compilation of all available data with records of this species. Next, the environmental requirements of $C$. irrorata were identified based on an analysis of hydrochemical conditions in representative springs, i.e., springs with low (local) human impact, with and without this species. A large spring area with ca. 700 individual springs and seeps in the central-western region of Poland was selected for the present study (Szczucińska, $2009,2014)$. Because $C$. irrorata is a conservative habitat specialist throughout its entire distribution, our research can provide model studies for crenic habitats at the European scale. We aimed to identify the role of $C$. irrorata as a potential indicator of water quality in springs, particularly in terms of biogenic and heavy metal pollution.

\section{METHODS}

Our compilation of records, made to document the distribution of C. irrorata in Poland, relies on i) peer-reviewed publications (scientific notes, articles, and books); ii) unpublished bachelor's, master's and doctoral theses; and iii) new results from the authors' investigations. The material includes all sources available from the beginning of the $20^{\text {th }}$ century until the present that include information on the occurrence of $C$. irrorata. The geographical locations specified in the records were critically verified, and the data were transformed into the UTM coordinate system (UTM grid) with $10 \times 10 \mathrm{~km}$ squares as basic units, using GNOMON 3.2 software for the graphical presentation of the data on the distribution of $C$. irrorata. Addi- tionally, the stage of C. irrorata (imago/larva), habitat type, and a brief area description were furnished in a summary table.

To determine the environmental preferences of C. irrorata, we analysed a broad spectrum of 25 physico-chemical water variables from 21 springs located in the Lubuska Upland (central-western Poland) (Fig. 1, Tab. 1). The larvae of $C$. irrorata were found in 13 springs (Tab. 1). The characteristics of the water in the selected springs have already been studied (Szczucińska, 2014), and the results of that study indicated a gradient of nutrient and trace metal components, demonstrating the relevance of the selected springs to the purpose of this study.

The water sampling procedures used to obtain this information have been explicitly described elsewhere (Szczucińska, 2014). In brief, water samples from each spring were taken five times (September 2012, December 2012, April 2013, July 2013, and October 2013) directly from groundwater outflows. The water temperature (digital thermometer ETI 2001, Electronic Temperature Instruments Ltd., Worthing, United Kingdom), electrical conductivity (EC) (conductivity meter CC-401, Elmetron Sp.j., Zabrze, Poland) and $\mathrm{pH}(\mathrm{pH}$ meter 315i, Wissenschaftlich-Technische Werkstätten GmbH, Weilheim, Germany) were measured immediately in the field. The analyses of other parameters were conducted in the laboratory following Polish and international norms. The analyses included primary components (bicarbonate, sulphate, chloride, silicate, magnesium, calcium, sodium), secondary components (total iron, potassium, nitrate, fluoride), minor components (phosphate, manganese, cadmium, chromium, copper, lead, zinc), and other parameters [ammonium, nitrite, total organic carbon (TOC), total water hardness (TWH)].

Differences in physico-chemical water parameters between springs with and without $C$. irrorata were tested with a non-parametric Mann-Whitney test. Further, water parameters with significant results on the Mann-Whitney test were used individually as independent variables in binary logistic regression models to predict the probability of occurrence of C. irrorata. All statistical analyses were performed using SPSS software (IBM Inc., Chicago, IL, USA).

\section{RESULTS}

\section{Distribution of $C$. irrorata in Poland}

Prior to this publication, 88 localities for $C$. irrorata had been documented in Poland (Tab. 2): 64 records were known up to 1999, and 24 records have been published since 2000. Furthermore, 18 new records have been added by the authors, giving 106 localities in total (Tab. 2). Overall, C. irrorata was found in the larval stage at 68 localities. These findings confirmed the exact habitat location and habitat type. Of these localities, $74 \%$ were springs, whereas 
$26 \%$ constituted streams, upper zones of rivers, and tributaries. In 38 cases of imago records, the nearest habitat types were given: $53 \%$ streams, $18 \%$ springs, and $29 \%$ records for which an exact habitat classification was not possible because of the presence of both spring and stream habitats or the lack of a precise description.

The current distribution of $C$. irrorata extends over the entire territory of Poland, but the species occurs sparsely in most regions and has not yet been observed in large areas (Fig. 2). There are only 3 regions in Poland with substantial concentrations of sites: between the Odra and Warta River valleys in the central-west, 15 records (UTM: WU10; -11;-20; WT07; -09; -18; -28,-39); in the Central Polish Lowlands, 6 records (CC85; -95; DC04; 13; -23); and in Roztocze, in the southeast, 6 records (FA49; -58;-67;-68; FB31) (Tab. 2). Further, C. irrorata is well distributed throughout the mountain regions of Poland, with records in Sudety in the southwest, in the Western and Central Carpathians in the south, in the Eastern Beskidy Mountains in the southeast, and in the Świętokrzyskie Mountains in the central part of Poland. However, the number of mountain localities is rather low,

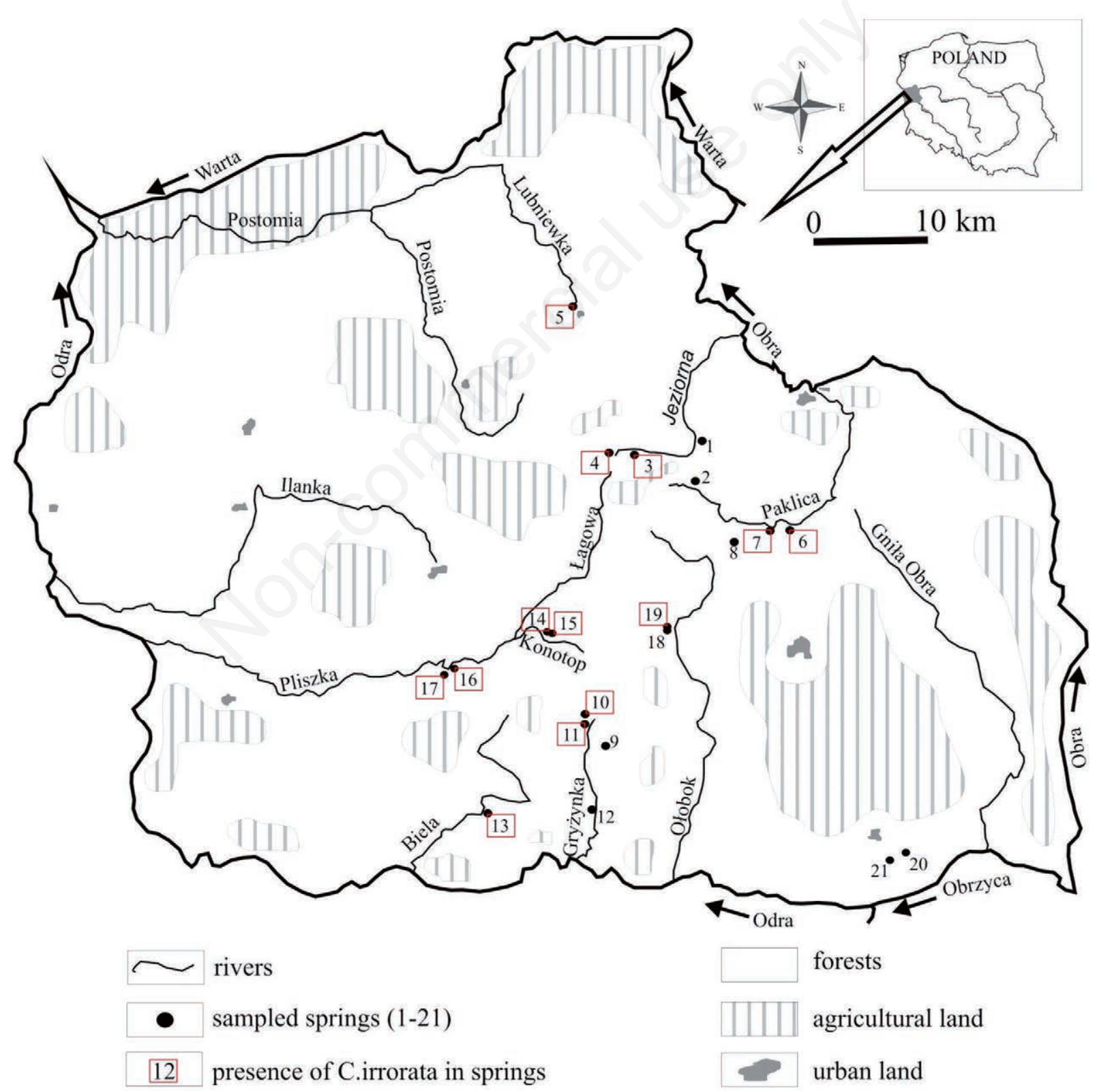

Fig. 1. Location of the 21 springs analysed for their water properties, with area characteristics. 
with a few small areas with greater concentrations of records identified in the Świętokrzyskie Mountains (UTM: DB93), Stołowe Mountains (UTM: WR98), Babia Góra (UTM: CV99), and Gorce Mountains (UTM: DV29). In other Polish regions, only single and widely scattered localities are known from the South Baltic Coastal Regions and Lake Districts in the north as well as from the Małopolska- and Silesian-Cracovian Upland in central Poland.

\section{Water characteristics of $\boldsymbol{C}$. irrorata habitats}

To determine the environmental preferences of $C$. irrorata, with particular emphasis on its potential as an indicator, we analysed the characteristics of the water from 21 representative springs from the central-western area, including 13 springs in which the presence of this species has been confirmed and 8 springs from which the species is known to be absent (Tab. 1). Our analyses showed that C. irrorata occurred over wide ranges of almost all measured water parameters (Fig. 3). However, the most remarkable discrepancies in presence/absence were observed with respect to nitrate. In detail, C. irrorata was almost exclusively observed in springs with low concentrations of nitrate of approximately $1.0 \mathrm{mg} \mathrm{L}^{-1}$ and not exceeding $20 \mathrm{mg} \mathrm{L}^{-1}$ (Fig. 3, Tab. 3). Statistically, the probability of occurrence of $C$. irrorata decreased significantly as $\mathrm{NO}_{3}$ concentrations increased (Fig. 4, Tab. 4). According to the corresponding binary logistic regression model, the probability of recording the species was less than $5 \%$ at a concentration of $32 \mathrm{mg} \mathrm{L}^{-1} \mathrm{NO}_{3}$ (Tab. 4). Furthermore, significantly lower values of $\mathrm{EC}, \mathrm{TWH}, \mathrm{Cl}$, $\mathrm{Mg}, \mathrm{Na}, \mathrm{SiO}_{2}, \mathrm{~K}$, and $\mathrm{F}$, as well as significantly higher values of $\mathrm{pH}$, were indicated for springs harbouring C. irrorata (Tab. 3). For three components $(\mathrm{Cl}, \mathrm{F}$, and $\mathrm{K}$ ) as well as for $\mathrm{pH}$ the results of logistic regression were also significant. Based on these regression results, the probability of recording the species was less than $5 \%$ at concentrations of $35 \mathrm{mg} \mathrm{L}^{-1} \mathrm{Cl}, 0.55 \mathrm{mg} \mathrm{L}^{-1} \mathrm{~F}$, and $5.2 \mathrm{mg}$ $\mathrm{L}^{-1} \mathrm{~K}$ (Tab. 4).

High concentrations of heavy metals $(\mathrm{Zn}, \mathrm{Pb}, \mathrm{Cu}, \mathrm{Cr}$, and (d), as well as the total levels of iron and of manganese, did not influence the presence of $C$. irrorata (Fig. 3, Tab. 3). In general, the median values of these parameters were equal in spring groups with and without $C$. irrorata or even slightly higher in habitats with C. irrorata. Moreover, the species was observed in certain springs with the highest seasonal (extreme) values of these metals, maximally reaching $0.23 \mathrm{mg} \mathrm{L}^{-1} \mathrm{Zn}, 0.13$ $\mathrm{mg} \mathrm{L}^{-1} \mathrm{~Pb}, 0.043 \mathrm{mg} \mathrm{L}^{-1} \mathrm{Cu}, 0.012 \mathrm{mg} \mathrm{L}^{-1} \mathrm{Cr}, 0.005 \mathrm{mg}$ $\mathrm{L}^{-1} \mathrm{Cd}, 19.0 \mathrm{mg} \mathrm{L}^{-1} \mathrm{Fe}$, and $3.3 \mathrm{mg} \mathrm{L}^{-1} \mathrm{Mn}$. These ex-

Tab. 1. Location and characteristics of 21 springs selected for physico-chemical analyses of water properties, with additional information on presence $(+) /$ absence $(-)$ of C. irrorata.

\begin{tabular}{|c|c|c|c|c|c|c|}
\hline \multirow[t]{2}{*}{ Spring number } & \multicolumn{2}{|c|}{ Geographical coordinates } & \multirow[t]{2}{*}{ River catchment } & \multirow[t]{2}{*}{ Outflow type } & \multirow[t]{2}{*}{ Outflow position } & \multirow[t]{2}{*}{ C. irrorata } \\
\hline & Longitude & Latitude & & & & \\
\hline 1 & 15.46389 & 52.41027 & Jeziorna & $\mathrm{D}$ & U. hillside & - \\
\hline 2 & 15.40443 & 52.36595 & Paklica & $\mathrm{D}-\mathrm{A}$ & U. hillside & - \\
\hline 3 & 15.32523 & 52.40692 & Jeziorna & $\mathrm{D}$ & U. hillside & + \\
\hline 4 & 15.30436 & 52.40742 & Jeziorna & $\mathrm{D}$ & U. hillside & + \\
\hline 5 & 15.17056 & 52.45591 & Lubniewka & $\mathrm{D}$ & U. hillside & + \\
\hline 6 & 15.50941 & 52.32510 & Paklica & D-A & U. hillside & + \\
\hline 7 & 15.51022 & 52.32503 & Paklica & $\mathrm{D}$ & U. hillside & + \\
\hline 8 & 15.45114 & 52.29362 & Paklica & $\mathrm{D}$ & U. hillside & - \\
\hline 9 & 15.28052 & 52.16915 & Gryżynka & D-A & U. hillside & - \\
\hline 10 & 15.27521 & 52.18211 & Gryżynka & D & U. hillside & + \\
\hline 11 & 15.27114 & 52.17522 & Gryżynka & D-A & U. hillside & + \\
\hline 12 & 15.27382 & 52.12755 & Gryżynka & $\mathrm{D}$ & U. hillside & - \\
\hline 13 & 15.13733 & 52.11305 & Biela & $\mathrm{D}$ & U. hillside & + \\
\hline 14 & 15.20443 & 52.25462 & Konotop & $\mathrm{D}$ & Hillside & + \\
\hline 15 & 15.20488 & 52.25375 & Konotop & $\mathrm{D}$ & Hillside & + \\
\hline 16 & 15.16449 & 52.24569 & Pliszka & $\mathrm{D}$ & Hillside & + \\
\hline 17 & 15.16357 & 52.24489 & Pliszka & $\mathrm{D}$ & U. hillside & + \\
\hline 18 & 15.37834 & 52.24591 & Ołobok & $\mathrm{D}$ & U. hillside & - \\
\hline 19 & 15.37840 & 52.24621 & Ołobok & $\mathrm{D}$ & U. hillside & + \\
\hline 20 & 15.72020 & 52.06730 & Obra & $\mathrm{D}$ & Hillside & - \\
\hline 21 & 15.71110 & 52.06521 & Obra & $\mathrm{D}$ & U. hillside & - \\
\hline
\end{tabular}

$D$, descending (gravity spring); D-A, descending-ascending (water discharged under pressure); U. hillside, under hillside. 
treme concentrations were 2 to 7 times greater in springs with $C$. irrorata than in springs without $C$. irrorata. Similarly, slightly higher concentrations of nutrients other than nitrate (TOC, $\mathrm{NH}_{4}, \mathrm{NO}_{2}$, and $\mathrm{PO}_{4}$ ) did not influence the distribution of the species in any way (Fig. 3, Tab. 3). C. irrorata was recorded at maximal values of $0.33 \mathrm{mg}$ $\mathrm{L}^{-1} \mathrm{NH}_{4}, 0.18 \mathrm{mg} \mathrm{L}^{-1} \mathrm{NO}_{2}$, and $0.86 \mathrm{mg} \mathrm{L}^{-1} \mathrm{PO}_{4}$.

\section{DISCUSSION}

\section{Patterns in the distribution of $C$. irrorata in Poland}

A compilation of available information on the occurrence of C. irrorata in Poland was urgently needed due to the species' legal protection since 2004. The law providing protection to this and other species is one of the strongest tools implemented for nature and diversity conservation at the national scale. Based on a summary of the distribution of Trichoptera in Poland (Tomaszewski, 1965), C. irrorata was almost exclusively reported from mountain regions (Sudety Mountains, Beskid Zachodni and Tatry Mountains) in southern Poland, with a single observation from the Masurian Lake District in the north, thus making it a very rare species on the national scale. Further investigations showed, however, that this species can also be found in spring-rich lowland and hill regions across the whole country. Nevertheless, the localities in which the species is currently found are also strongly scattered, suggesting that it is rather uncommon in Poland. Furthermore, a strong tendency to occupy only small spring areas or certain locations in ostensibly homogenous spring-reach areas is evident. This pattern is well documented from the Tanew (Buczyńska, 2010) and Młynówka (Majecki, 2006) River valleys as well as from mountains: Stołowe (Michejda, 1954), Gorce (Szczęsny, 1975, 1986), and Świętokrzyskie (Szczęsny, 1990), where C. irrorata was found more frequently only in a few groundwater outflow zones. This general pattern corresponds well to the knowledge about the patchy distribu-

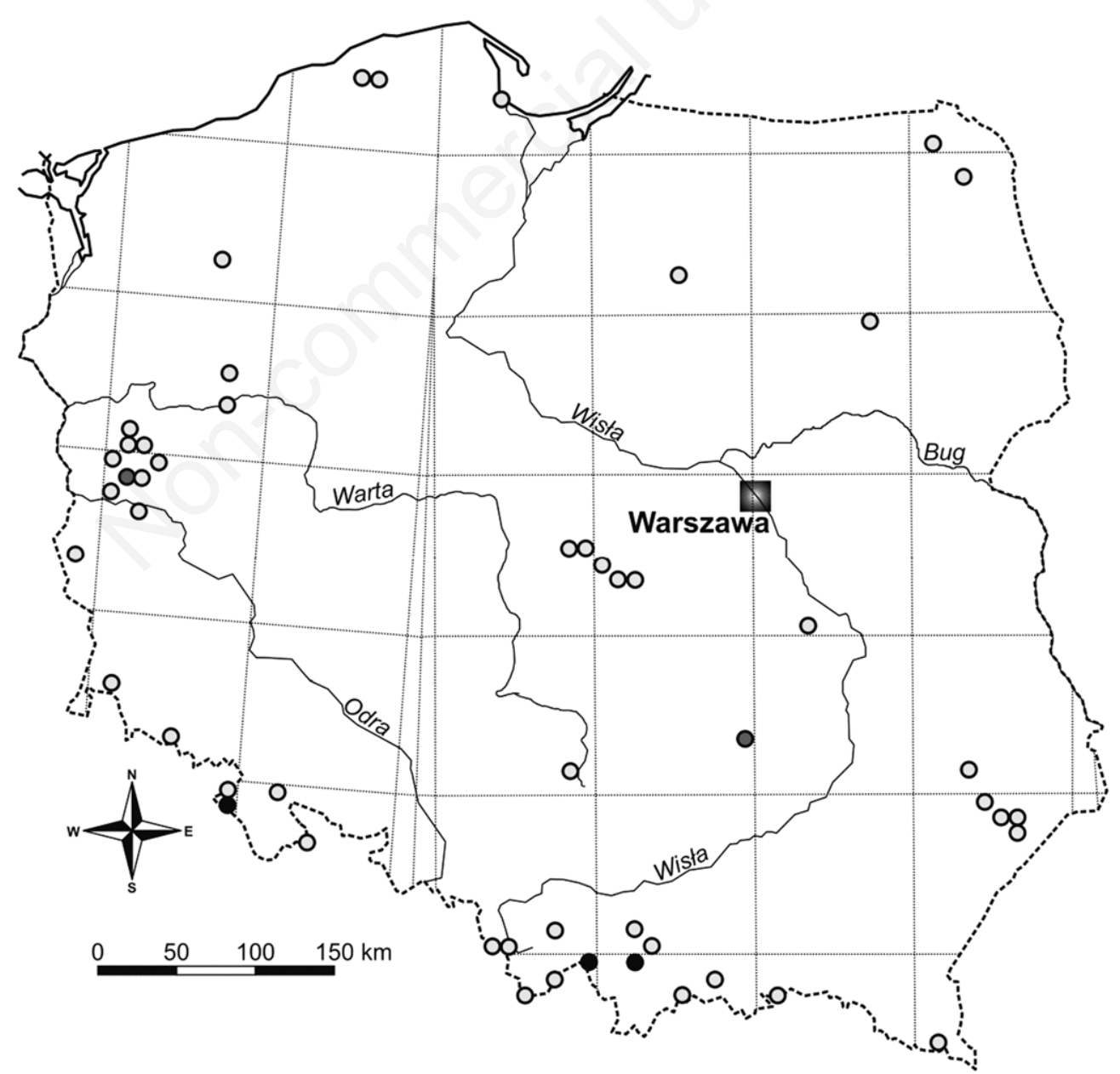

Fig. 2. Distribution of C. irrorata in Poland. The colours of symbols refer to number of sites in a single grid: light grey, 1-4 sites; dark grey, $5-8$ sites; black, $\geq 9$ sites. 
Tab. 2. Summary of sites for C. irrorata in Poland, with information on location (UTM square), number of records, stage, habitat type and brief description of the area, with references.

\begin{tabular}{|c|c|c|c|}
\hline UTM & Records & Stage & Notes to habitat and location with references \\
\hline CA40 & 1 & $\operatorname{Im}$ & Stream Leśnica (Szczęsny, 1986) \\
\hline CA50 & 2 & $\operatorname{Im}$ & Spring and stream Leśnica (Szczęsny, 1986) \\
\hline CA71 & 1 & $\mathrm{La}$ & Stream Potok Wielka Puszcza and its tributaries (Zaćwilichowska, 1964) \\
\hline CB81 & 2 & Im & $\begin{array}{l}\text { Zygmunt's and river Wiercica's springs (Riedel, 1972) } \\
\text { Spring of river Wiercica (Czachorowski, 1990) }\end{array}$ \\
\hline CC85 & 1 & $\mathrm{La}$ & Springs of river Linda (Majecki, 2006) \\
\hline CC95 & 1 & $\mathrm{La}$ & Spring of river Ciosenka (Majecki, 2006) \\
\hline CF43 & 1 & $\mathrm{La}$ & Springs of stream Kamienny Potok (Ciechanowski, 2004) \\
\hline CV57 & 1 & $\operatorname{Im}$ & Stream Racza (Szczęsny, 1986) \\
\hline CV78 & 2 & $\operatorname{Im}$ & Spring and stream Żabnica (Szczęsny, 1986) \\
\hline CV99 & 10 & $\operatorname{Im}$ & $\begin{array}{l}\text { Mount Babia Góra: Markowa in Zawoja (Dziędzielewicz, 1911); Zawoja (Dziędzielewicz, 1920); ? (Racięcka, } \\
\text { 1933); stream at Krowiarki, karst spring and stream at Gruba Jodła, River Skawica in Zawoja (Botosaneanu, } \\
\text { 1965); streams: Potok Suchy, Dejaków Potok, tributary of Markowy Potok (Sowa and Szczęsny, 1970); stream } \\
\text { Przywarówka (Szczęsny, 1986) }\end{array}$ \\
\hline DA22 & 1 & $?$ & Myślenice (Racięcka, 1933) \\
\hline DA30 & 2 & $\operatorname{Im}$ & Spring and stream Stradomka (Szczęsny, 1986) \\
\hline DB93 & 7 & $\mathrm{La}$ & $\begin{array}{l}\text { Spring and stream Dębno, tributary of stream Podłysica, spring of stream Łysiczka, stream Czarny Potok } \\
\text { (Szczęsny, 1990) }\end{array}$ \\
\hline DC04 & 2 & $\mathrm{La}$ & Helocrenes at river Młynówka (Majecki, 2006) \\
\hline DC13 & 1 & $\mathrm{La}$ & Helocrene at river Mroga (Majecki, 2006) \\
\hline DC23 & 1 & $\mathrm{La}$ & Spring stretch of river Rewica (Majecki, 2006) \\
\hline DE62 & 3 & $\mathrm{La}$ & Helocrenes at river Łyna (Szczepański, 2003) \\
\hline DV29 & 11 & $\operatorname{Im}$ & Spring, stream and tributary of stream Poniczanka (Szczęsny, 1986); stream Olszowy (Szczęsny, 1975) \\
\hline DV57 & 2 & $\operatorname{Im}$ & Stream Pieniński Potok and spring on Toporzyska (Riedel, 1978) \\
\hline DV78 & 1 & Im & Stream Mała Roztoka Ryterska (Riedel, 1972) \\
\hline $\mathrm{EC} 30$ & 1 & $\mathrm{La}$ & Springs at river Zagożdżanka in Królewskie Źródło reserve (Pachocka, 2003) \\
\hline ED79 & 1 & $\mathrm{La}$ & Stream in Kalinowo reserve (Czachorowski et al., 2000b) \\
\hline EV17 & 1 & $\operatorname{Im}$ & Stream Ropka (Szczęsny, 1986) \\
\hline FA49 & 2 & $\mathrm{La}$ & Springs of stream Krupiec (Buczyńska, 2010) \\
\hline FA58 & 1 & $\mathrm{La}$ & River Tanew (Buczyńska, 2010) \\
\hline FA67 & 1 & $\mathrm{La}$ & Springs of river Tanew (Buczyńska, 2010) \\
\hline FA68 & 1 & $\mathrm{La}$ & River Tanew (Buczyńska, 2010) \\
\hline FB31 & 1 & $\mathrm{La}$ & River Wieprz (Buczyńska, 2010) \\
\hline FE38 & 1 & $\mathrm{La}$ & Springs at Lake Wigry (Demel, 1922) \\
\hline FF10 & 1 & $\mathrm{La}$ & Helocren at river Czarna Hańcza (Buczyńska and Buczyński, 2014) \\
\hline FV14 & 1 & $\operatorname{Im}$ & Mountainside of Połonina Caryńska (Riedel, 1966) \\
\hline VT83 & 1 & $\mathrm{La}$ & Spring at stream Pstrąg (Rychła and Buczyńska, 2013) \\
\hline WR98 & 4 & $\mathrm{La}$ & Springs and streams in Góry Stołowe mountains (Michejda, 1954) \\
\hline WR99 & 10 & $\mathrm{La}$ & Springs and streams in Góry Stołowe mountains (Michejda, 1954) \\
\hline WS15 & 1 & $\operatorname{Im}$ & Stream Czarny Strumień (Tomaszewski, 1932) \\
\hline WS52 & 1 & $\mathrm{La}$ & Spring of river Łomnica (Tomaszewski, 1932) \\
\hline WT07 & 1 & $\mathrm{La}$ & Rheocrene at river Biela (present work) \\
\hline WT09 & 1 & $\mathrm{La}$ & Spring at river Ilanka (present work) \\
\hline WT18 & 7 & $\mathrm{La}$ & Rheocrenes at rivers Gryżynka, Konotop, and Pliszka (present work) \\
\hline WT26 & 2 & $\mathrm{La}$ & Helocrenes at river Łącza (present work) \\
\hline WT28 & 1 & $\mathrm{La}$ & Rheocrene at river Ołobok (present work) \\
\hline WT39 & 2 & $\mathrm{La}$ & Rheocrenes at river Paklica (present work) \\
\hline WU10 & 1 & $\mathrm{La}$ & Rheocrene at river Jeziorna (present work) \\
\hline WU11 & 1 & $\mathrm{La}$ & Rheocrene at river Lubniewka (present work) \\
\hline WU20 & 1 & $\mathrm{La}$ & Rheocrene at river Jeziorna (present work) \\
\hline WU73 & 1 & $\mathrm{La}$ & Spring at Lake Kubek (Adamek, 2006) \\
\hline WU75 & 1 & $\mathrm{La}$ & Spring at fish pond (Adamek, 2004) \\
\hline WV62 & 1 & $\mathrm{La}$ & Stream and tributary of Lake Lubie (Pietrzak, 2000) \\
\hline XA44 & 1 & $\mathrm{La}$ & Spring at river Łupawa (Veith, 2006) \\
\hline WA54 & 1 & $\mathrm{La}$ & River Łupawa (Veith, 2006) \\
\hline XR29 & 1 & $\mathrm{La}$ & Springs at town Bardo (Tomaszewski, 1932) \\
\hline XR36 & 1 & $\operatorname{Im}$ & Springs of stream Kleśnica (Tomaszewski, 1932) \\
\hline
\end{tabular}

Im, imago; La, larvae. 
tion of this species in other European countries and, consequently, to its classification as a rare species on a continental scale (Hoffsten and Malmqvist, 2000; Graf et al., 2006, 2008; Graf and Schmidt-Kloiber, 2011). The patchy large-scale occurrence of $C$. irrorata surely results from its strictly stenotopic preferences for small and highly isolated habitats such as springs. Given the poor flying ability of imagines, which has also been demonstrated in spring habitats by Hoffsten (2004), the regional rarity of the species may, furthermore, arise from the high degree of isolation of pristine and near-pristine crenic ecosystems offering the optimal conditions required by this species.

At present, the occupancy of $C$. irrorata is highest in three Polish regions: between the Odra and Warta River valleys in the central-west, in the Central Polish Lowlands, and in Roztocze in the southeast. Most of the sites for $C$. irrorata in the central-western region have only recently been discovered and are, thus, first reported in this publication. It is noteworthy that this area has the highest frequency of occurrence of $C$. irrorata in Poland reported to date: the species was found in 13 of 21 investigated springs $(62 \%)$. Moreover, the western region of the country is potentially important for obtaining further records of $C$. irrorata and is consequently of high importance for the conservation of crenic fauna because approximately
700 individual springs and seeps have been reported as a result of detailed groundwater outflow mapping conducted during the past decade (Szczucińska, 2009, 2014). For comparison, the frequency of occurrence of the species in the 2 other mentioned regions of central and eastern Poland is much lower, 36\% (Majecki, 2006) and 27\% (Buczyńska, 2010), respectively. Further, a study of 66 lowland springs in north-eastern Poland (Masurian Lake District) showed that only $4.5 \%$ are inhabited by $C$. irrorata (Szczepański, 2003). The current frequency data show a continuous decrease towards the east and north, suggesting a climate-related effect. A brief comparison with the average long-term (1981-2010) air temperatures in the principal cities of these regions (western: $8.9^{\circ} \mathrm{C}$, central and south-eastern: $8.4^{\circ} \mathrm{C}$, northeastern: $7.6^{\circ} \mathrm{C}$ ) (http://www.pogodynka.pl/polska/daneklimatyczne/) generally supports this hypothesis at the national scale. However, the frequency values of $42 \%$ from the region of Finland (Ilmonen, 2008), with average annual air temperatures of approximately $4^{\circ} \mathrm{C}$ (Pirinen et al., 2012), contradict the hypothesis. Therefore, our interpretation should be treated with caution because it requires detailed faunistic knowledge of the species to provide a firm basis for testing the hypothesis of a climate-related effect. The picture obtained of the distribution of C. irrorata may in-
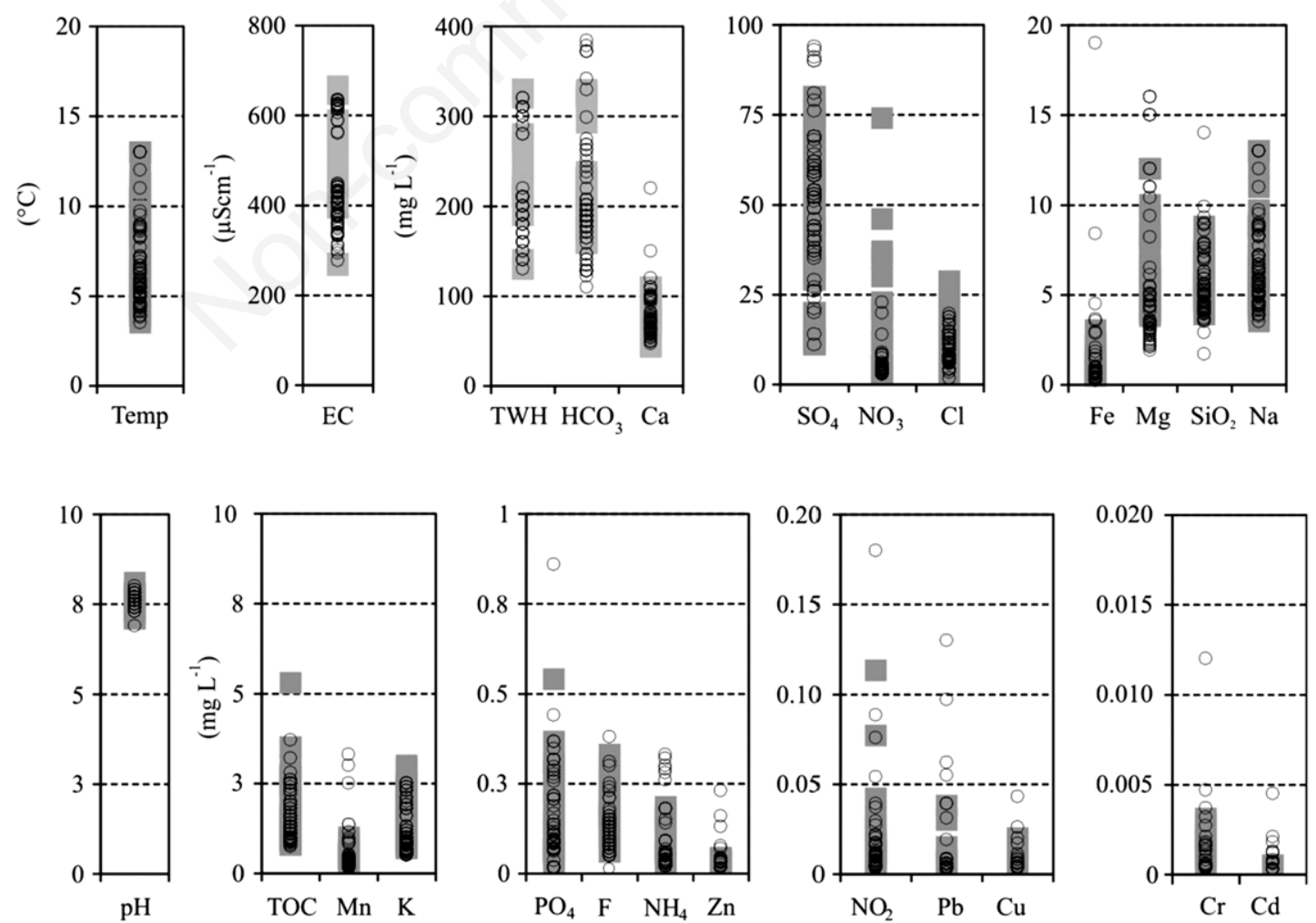

Fig. 3. Presence (black circles) and absence (grey squares) of C. irrorata in relationship to physico-chemical parameters. 
clude a margin of error due to the variation in the recognition of Trichoptera from region to region in Poland and due to the use of data from different periods. However, such a margin of error is unavoidable and is characteristic of analyses of many species in different countries. This difficulty has also been highlighted as one of the important obstacles by Hering et al. (2009) in terms of potential analyses of the impact of climate on Trichoptera at the European scale.

\section{Environmental preferences and potential of $C$. irrorata as an indicator species}

Knowledge of the influence of the physical and chemical properties of water on C. irrorata and, thus, of its potential as an indicator of water quality is still very poor. Therefore, the most noteworthy information presented by our study is an evidence of the sensitivity of the species to nitrate and chloride. For nitrate, our regression model predicted with a correctness of $72 \%$ that a concentration greater than $32 \mathrm{mg} \mathrm{L}^{-1}$ might be the limiting value for $C$. irrorata in springs. Such a level of nitrate exceeds its natural content in groundwater and thus is, in itself, evidence

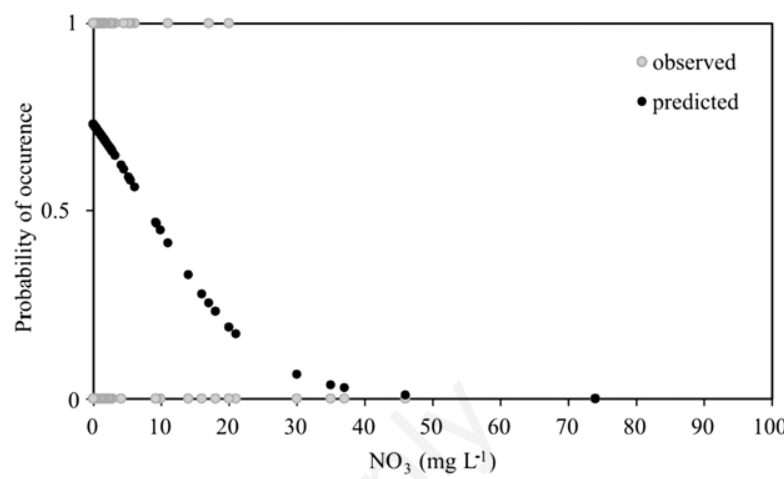

Fig. 4. Observed (grey dots) and predicted (black dots) occurrence of $C$. irrorata across nitrate gradient (details of the model equation are given in Tab. 4).

Tab. 3. Comparison of physico-chemical parameters of water (median, minimum and maximum values) for 21 springs with and without C. irrorata, with results of Mann-Whitney-tests.

\begin{tabular}{|c|c|c|c|c|c|c|}
\hline \multirow[t]{2}{*}{ Variable } & \multirow[t]{2}{*}{ Unit } & \multicolumn{2}{|c|}{ Presence of $C$. irrorata $(n=65)$} & \multicolumn{2}{|c|}{ Absence of $C$. irrorata $(n=40)$} & \multirow[t]{2}{*}{$Z$ value with $P$} \\
\hline & & Median & Min-max & Median & Min-max & \\
\hline \multicolumn{7}{|c|}{ Physical components } \\
\hline Temp. & ${ }^{\circ} \mathrm{C}$ & 9.4 & $7.0-13.2$ & 9.6 & $6.2-13.0$ & -1.009 \\
\hline $\mathrm{pH}$ & - & 7.7 & $6.9-8.0$ & 7.6 & $7.1-8.1$ & $-2.306^{*}$ \\
\hline $\mathrm{EC}$ & $\mu \mathrm{S} \mathrm{cm} \mathrm{cm}^{-1}$ & 414 & $277-635$ & 474 & $267-665$ & $-2.534^{*}$ \\
\hline \multicolumn{7}{|c|}{ Primary components } \\
\hline $\mathrm{HCO}_{3}$ & $\mathrm{mg} \mathrm{L}^{-1}$ & 177 & $110-384$ & 204 & $159-329$ & -1.360 \\
\hline $\mathrm{SO}_{4}$ & & 53 & 11-94 & 50 & $11-80$ & -0.579 \\
\hline $\mathrm{Cl}$ & & 9.0 & $0-18.0$ & 12.0 & $1.4-27.0$ & $-2.821^{* *}$ \\
\hline $\mathrm{Si}$ & & 5.0 & $1.7-14.0$ & 5.8 & $3.9-8.8$ & $-2.387^{*}$ \\
\hline $\mathrm{Mg}$ & & 3.5 & $1.9-16.0$ & 5.9 & $3.8-12.0$ & $-3.879^{* * *}$ \\
\hline $\mathrm{Ca}$ & & 72 & $47-220$ & 78.5 & $43-110$ & -1.644 \\
\hline $\mathrm{Na}$ & & 5.9 & $3.5-13.0$ & 7.5 & $3.3-10.0$ & $-2.079^{*}$ \\
\hline \multicolumn{7}{|c|}{ Secondary components } \\
\hline Tot. Fe & $\mathrm{mg} \mathrm{L}^{-1}$ & 0.3 & $0.02-19.0$ & 0.3 & $0.02-2.9$ & -0.185 \\
\hline $\mathrm{K}$ & & 0.9 & $0.5-2.5$ & 1.3 & $0.69-3.0$ & $-3.287^{* *}$ \\
\hline $\mathrm{NO}_{3}$ & & 1.0 & $0-20.0$ & 2.1 & $0-74.0$ & $-2.77^{* *}$ \\
\hline $\mathrm{F}$ & & 0.10 & $0-0.38$ & 0.16 & $0.05-0.33$ & $-3.225^{* *}$ \\
\hline \multicolumn{7}{|c|}{ Minor components } \\
\hline $\mathrm{PO}_{4}$ & $\mathrm{mg} \mathrm{L}^{-1}$ & 0.066 & $0-0.86$ & 0.050 & $0-0.54$ & -0.722 \\
\hline $\mathrm{Mn}$ & & 0.14 & $0-3.3$ & 0.09 & $0.001-0.84$ & -1.399 \\
\hline $\mathrm{Cd}$ & & 0.00002 & $0-0.005$ & 0.00002 & 0-0.001 & -0.035 \\
\hline $\mathrm{Cr}$ & & 0.0002 & $0-0.012$ & 0.0003 & $0-0.003$ & -0.357 \\
\hline $\mathrm{Cu}$ & & 0.001 & $0-0.043$ & 0.001 & $0-0.020$ & -0.056 \\
\hline $\mathrm{Pb}$ & & 0.001 & $0-0.13$ & 0.0006 & $0-0.038$ & -0.468 \\
\hline $\mathrm{Zn}$ & & 0.0025 & $0-0.23$ & 0.0028 & $0-0.044$ & -0.324 \\
\hline \multicolumn{7}{|c|}{ Other components } \\
\hline $\mathrm{NH}_{4}$ & $\mathrm{mg} \mathrm{L}^{-1}$ & 0.01 & $0-0.33$ & 0.03 & $0-0.17$ & -1.63 \\
\hline $\mathrm{NO}_{2}$ & & 0.007 & $0-0.18$ & 0.009 & $0-0.13$ & -0.601 \\
\hline TOC & & 1.3 & $0.74-3.7$ & 1.6 & $0.78-5.3$ & -1.857 \\
\hline TWH & & 200 & $130-320$ & 225 & $130-330$ & $-2.543^{*}$ \\
\hline
\end{tabular}

EC, electrical conductivity; TOC, total organic carbon; TWH, total water hardness; ${ }^{*} P \leq 0.05 ;{ }^{* *} P \leq 0.01$; ${ }^{* * *} P \leq 0.001$. 
of contamination (Chelmicki et al., 2011) that might be associated with local agriculture or domestic/tourist activities in the studied area. Our predictions of the effect of nitrate on the occurrence of $C$. irrorata, although they are based on a relatively small sample size, appear to be highly consistent with findings from other European regions, e.g., Rhineland-Palatinate (Germany), where more than $90 \%$ of the springs occupied by this species had a concentration of nitrate less than $30 \mathrm{mg} \mathrm{L}^{-1}$ (Schindler, 2004). A very low tolerance of pollution by biogenic contaminants such as phosphate and ammonium has also been shown for the entire family Lepidostomatidae and particularly for another species belonging to this family (Lasiocephala basalis) in Mediterranean streams (Bonada et al., 2004). These findings suggest that species in the family Lepidostomatidae generally have the potential to serve as indicators of biogenic pollution. For chloride, our regression model predicted an upper limit of $35 \mathrm{mg} \mathrm{L}^{-1}$ $\mathrm{Cl}$, again agreeing well with corresponding results from the German Rhineland-Palatinate spring region (Schindler, 2004). Additionally, a strong preference for low concentrations of $\mathrm{Cl}$ has also been documented at the family level in Lepidostomatidae (Bonada et al., 2004). In contrast, however, there is evidence that the genus Lepidostoma (Lepidostomatidae) can survive for $48 \mathrm{~h}$ at chloride pollution levels of up to $6000 \mathrm{mg} \mathrm{L}^{-1}$ (Williams et al., 2000). This value exceeds the limit predicted by our regression model by almost 200 -fold, but note also that $50 \%$ of the tested individuals died after $96 \mathrm{~h}$ of exposure to this extremely high chloride concentration (Williams et al., 2000). These results indicate that a low level of chloride concentration might be required for long-term occupancy of a site by representatives of the Lepidostomatidae, including $C$. irrorata.

The effects of other water components are of low importance for the distribution of $C$. irrorata. Our results slightly support the observation that $C$. irrorata prefers higher $\mathrm{pH}$ values (Ilmonen, 2008) and lower values of water hardness (Schindler, 2004). However, based on currently available results, the relatively weak differences, although statistically significant, of these and several other components (e.g., EC, $\mathrm{Si}, \mathrm{Mg}, \mathrm{Na}$, and $\mathrm{K}$ ) between springs with and without $C$. irrorata in our study area do not permit these components to be used as predictive factors for the occurrence of this species. It appears that other morphological characteristics, such as the total area and minerogenic area associated with brooks (Ilmonen, 2008), as well as the occurrence of surrounding deciduous vegetation in association with specific and more diverse substrate types (Hahn, 2000; Schindler, 2004), are more important factors. In this context, Czachorowski (1999) specified helorheocrenes as the general habitat of C. irrorata in Poland. However, among the springs examined in the current study, more than $50 \%$ cannot be simply included in a particular category of spring types. The basic habitat-related approach to morphological typing of the springs (Thienemann, 1924) inhabited by this species still appears to be unsatisfactory as a method of classification and is too simplified to describe the more complex nature of spring morphology, especially on the national scale. This problem has also been discussed by von Fumetti and Nagel (2011) in the context of spring invertebrate assemblages.

Heavy metals also affect the water quality of springs for aquatic organisms and for humans because of potential toxicity and potential accumulation. However, the relationship between these pollutants and caddisfly representatives is rather complex. In general, the effects of heavy metals on the order Trichoptera (structure and abundance) in streams appear to be of minor importance, although slightly negative effects (Qu et al., 2010) as well as slightly positive effects (Hirst et al., 2002) of particular heavy metals have been observed. However, various levels of sensitivity have been documented for individual taxa within the order Trichoptera. For example, Polycen-

Tab. 4. Results of logistic regression for selected physico-chemical parameters of water for 21 springs.

\begin{tabular}{|c|c|c|c|c|c|c|c|}
\hline Variable & Model correct (\%) & $\mathbf{R}$ & B0 & B1 & $\operatorname{Exp}(B)$ & $P$ & Conc. of $5 \%$ prob. \\
\hline $\mathrm{NO}_{3}$ & 72.4 & -0.22 & 0.993 & -0.122 & 0.885 & 0.003 & 32 \\
\hline $\mathrm{Cl}$ & 72.4 & -0.25 & 1.934 & -0.136 & 0.87 & 0.001 & 35 \\
\hline $\mathrm{F}$ & 65.7 & -0.21 & 1.651 & -8.262 & 0.0003 & 0.004 & 0.55 \\
\hline K & 63.8 & -0.20 & 1.622 & -0.874 & 0.42 & 0.006 & 5.2 \\
\hline $\mathrm{pH}$ & 64.8 & 0.11 & -17.10 & 2.318 & 10.15 & 0.050 & 6.2 \\
\hline $\mathrm{SiO}_{2}$ & 60.0 & 0.000 & 1.284 & -0.138 & 0.87 & 0.236 & - \\
\hline $\mathrm{Mg}$ & 59.0 & -0.046 & 1.000 & -0.085 & 0.92 & 0.129 & - \\
\hline $\mathrm{EC}$ & 58.1 & -0.08 & 1.959 & -0.003 & 0.99 & 0.085 & - \\
\hline TWH & 57.1 & -0.06 & 1.774 & -0.006 & 0.99 & 0.109 & - \\
\hline $\mathrm{Na}$ & 57.1 & 0.000 & 1.286 & -0.117 & 0.89 & 0.222 & - \\
\hline
\end{tabular}

$R$, regression coefficient; $B 0$ and B1, coefficients in regression equation; Exp $(B)$, odds ratio, Conc. of $5 \%$ prob., estimated concentrations for $5 \%$ probability of occurrence of $\mathrm{C}$. irrorata; EC, electrical conductivity; TWH, total water hardness. 
tropus sp. and Apsilochorema sp. are known to show positive responses to metal contamination, whereas Ryacophila sp. and Sericostriata sp. are highly sensitive to such contamination (Qu et al., 2010). For the family Lepidostomatidae, evidence of significantly negative effects of lead and nickel as well as slightly negative effects of cadmium and zinc have been found for Lepidostoma sp. in Chinese streams (Qu et al., 2010), suggesting that $C$. irrorata, as a representative of the same family, might show a similar sensitivity to these heavy metals. Surprisingly, high concentrations of neither these nor the other metals considered influenced the presence of $C$. irrorata in our study area in any way. Given that the maximal values for cadmium, zinc, and lead in our study area were seasonally approximately 10,3 , and 2 times, respectively, higher than in the studied Chinese streams, our results indicate that $C$. irrorata adapts well to habitats that are at least moderately polluted by heavy metals. Consequently, no potential for this species as an indicator of metal contamination in spring water can be demonstrated to date. However, it should be stressed that the concentrations of heavy metals show strong seasonality (Szczucińska et al., 2010). The highest concentrations are usually observed in early spring. One may speculate whether contamination during this season is of importance for i. a. the early stage of the life cycle.

\section{CONCLUSIONS}

The analysis in this study of the distribution of $C$. irrorata at the national scale showed that the species occurs in the entire territory of Poland. Nevertheless, the localities at which the species is currently found are also strongly scattered, suggesting that the species is relatively uncommon at the national scale. This general pattern corresponds well to that found for the species in other European countries. Consequently, this pattern is consistent with the classification of $C$. irrorata as a rare species at the continental scale (Hoffsten and Malmqvist, 2000; Graf et al., 2006, 2008; Graf and Schmidt-Kloiber, 2011). Further, the data compilation showed that the species occurs most frequently in the central-western region of Poland and indicated a geographically biased distribution pattern with a continuous decrease towards the east and the north-east. However, the causes of this pattern could not be explicitly identified.

In terms of the environmental preferences of the species, a comparison of the characteristics of water in springs with and without $C$. irrorata showed that the species is most strongly associated with habitats characterised by low nitrate and chloride. Therefore, the species is potentially a strong candidate for use in the bioassessment of crenic ecosystems in terms of biogenic and salt pollution. In contrast, no effect of heavy metals or of iron and manganese was found. These results suggested that C. irrorata is relatively insensitive to these metals and is not a potential indicator of metal pollution. In this context and in a broad sense, C. irrorata can be used as an indicator of water quality, with crucial implications for human health, because nitrate is a well-known toxic and harmful substance. In ecological terms, this caddisfly species can serve to determine environmental health because springs with $C$. irrorata can be considered free from negative processes such as eutrophication.

\section{ACKNOWLEDGMENTS}

The hydrochemical spring data were obtained through the Polish Ministry of Science and Higher Education research (grant no. NN306035040). We would like to thank to the anonymous reviewers for their valuable comments and a significant improvement of the final version of the manuscript.

\section{REFERENCES}

Adamek H, 2004. [Nowe stanowisko Crunoecia irrorata w Polsce].[Article in Polish]. Trichopteron 13:3.

Adamek H, 2006. [Chruściki źródlisk jez. Kubek i kilka uwag o preferencjach siedliskowych Crunoecia irrorata w Polsce].[Article in Polish]. Trichopteron 22:4-6.

Barquín J, Death RG, 2009. Physical and chemical differences in karst springs of Cantabria, northern Spain: do invertebrate communities correspond? Aquat. Ecol. 43:445-455.

Bonada N, Zamora-Muñoz C, Rieradevall M, Prat N, 2004. Ecological profiles of caddisfly larvae in Mediterranean streams: implications for bioassessment methods. Environ. Pollut. 132:509-521.

Botosaneanu L, 1965. [Neue Trichopterologische fänge in Polen, Rumänien und Bulgarien].[Article in German]. Latvijas Entomologs 10:53-60.

Buczyńska E, 2008. The caddisflies (Trichoptera) of springs in the Roztocze region (south-eastern Poland). Annales Univ. Mariae Curie-Skłodowska, sec. C 63:13-22.

Buczyńska E, 2010. [Chruściki (Trichoptera) Roztocza]. [PhD Thesis in Polish]. Maria Curie-Skłodowska Univ., Lublin.

Buczyńska E, Buczyński P, 2014. Caddisflies (Trichoptera) of the Polish part of the Lithuanian Lake District: new data, state of knowledge and research perspectives. Acta Biol. 21:37-56.

Cantonati M, Füreder L, Gerecke R, Jüttner I, Cox EJ, 2012. Crenic habitats, hotspots for freshwater biodiversity conservation: toward an understanding of their ecology. Freshw. Sci. 31:463-480.

Chelmicki W, Jokiel P, Michalczyk Z, Moniewski P, 2011. Distribution, discharge and regional characteristics of springs in Poland. Episodes 34:244-256.

Ciechanowski M, 2004. [Skarby sopockiej przyrody. Najcenniejsze fragmenty miejskiej zieleni]. [Book in Polish]. Department of Engineering and Environmental Protection of Municipal Office Publishers, Sopot.

Czachorowski S, 1990. Caddisflies (Trichoptera) of the springs of the Kraków-Częstochowa and Miechów Uplands (Poland). Acta Hydrobiol. 32:391-405.

Czachorowski S, 1999. [Chruściki (Trichoptera) źródeł Polski stan poznania]. [Book's chapter in Polish]. In: W. Biesiadka 
and S. Czachorowski (eds.), Źródła Polski. Stan badań, monitoring i ochrona. Higher Pedagogical School Publishers, Olsztyn:59-72.

Czachorowski S, Buczyński P, Walczak U, Pakulnicka J, 2000a. [Gatunki osłonowe (parasolowe) w ochronie owadów]. [Article in Polish]. Przegl. Przyr. 11:139-148.

Czachorowski S, Grużewski M, Pakulnicka J, 2000b. [Chruściki (Trichoptera) i chrząszcze wodne (Coleoptera) źródeł i ich odpływów okolic Drozdowa (północno-wschodnia Polska)]. [Article in Polish]. Przegl. Przyr. 11:25-28.

Demel K, 1922. [Fauna zimowa źródeł wigierskich]. [Article in Polish]. Prace Stacji Hydrob. na Wigrach. Inst. im. M. Nenckiego 1:1-27.

Dziędzielewicz J, 1911. [Owady siatkoskrzydłe (Neuropteroidae) zebrane w zachodnich Karpatach w roku 1909]. [Article in Polish]. Sprawozdanie Komisyi Fizyograficznej, Kraków 45:39-44.

Dziędzielewicz J, 1920. [Owady siatkoskrzydłowate ziem Polski (Insecta neuropteroidae Poloniae terrarum)]. [Article in Polish]. Rozprawy i Wiadomości z Muzeum Dzieduszyckich, Lwów 4:1-72.

Galas J, 2005. Human impact on physical and chemical properties of springs from Cracow-Częstochowa Upland (southern Poland). Pol. J. Ecol. 53:329-341.

Gerecke R, Franz H, Cantonati M, 2009. Invertebrate diversity in springs of the National Park Berchtesgaden (Germany): relevance for long-term monitoring. Verh. Internat. Verein. Limnol. 30:1229-1233.

Glazier DS, 1991. The fauna of North American temperate cold springs: patterns and hypotheses. Freshwater Biol. 26:527-542.

Graf W, Schmidt-Kloiber A, 2011. Additions to and update of the Trichoptera Indicator Database, ver. 5.0. Available from: www.freshwaterecology.info.

Graf W, Murphy J, Dahl J, Zamora-Muñoz C, López-Rodríguez MJ, Schmidt-Kloiber A, 2006. Trichoptera Indicator Database. Euro-limpacs project, Workpackage 7 - Indicators of ecosystem health, ver. 5.0. Available from: www.freshwaterecology.info.

Graf W, Murphy J, Dahl J, Zamora-Muñoz C, López-Rodríguez MJ, 2008. Trichoptera, p. 1-388. In: A. Schmidt-Kloiber and D. Hering (eds.), Distribution and ecological preferences of European freshwater organisms. Pensoft Publishers, SofiaMoscow.

Hahn HJ, 2000. Studies on classifying of undisturbed springs in southwestern Germany by macrobenthic communities. Limnologica 30:247-259.

Hering D, Schmidt-Kloiber A, Murphy J, Lücke S, ZamoraMuñoz C, López Rodríguez MJ, Huber T, Graf W, 2009. Potential impact of climate change on aquatic insects: A sensitivity analysis for European caddisflies (Trichoptera) based on distribution patterns and ecological preferences. Aquat. Sci. 71:3-14.

Hirst H, Jüttner I, Ormerod J, 2002. Comparing the responses of diatoms and macroinvertebrates to metals in upland streams of Wales and Cornwall. Freshwater Biol. 47:1752-1765.

Hoffsten P-O, 2004. Flight-morphology in relation to site-occupancy in caddisflies. Freshwater Biol. 49:810-817.

Hoffsten P-O, Malmqvist B, 2000. The macroinvertebrate fauna and hydrogeology of springs in central Sweden. Hydrobiologia 436:91-104.
Ilmonen J, 2008. Crunoecia irrorata (Curtis) (Trichoptera: Lepidostomatidae) and conservation of boreal spring: indications of clustering of red-listed species. Aquat. Conserv. 18:6-18.

Ilmonen J, Mykrä H, Virtanen R, Paasivirta L, Muotka T, 2012. Responses of spring macroinvertebrate and bryophyte communities to habitat modification: community composition, species richness, and redlisted species. Freshw. Sci. 31:657-667.

Majecki J, 2006. [Chruściki (Trichoptera) regionu łódzkiego]. [Habilitation Thesis in Polish]. Univ. of Łódź Publishers, Łódź.

Martin P, Brunke M, 2012. Faunal typology of lowland springs in northern Germany. Freshw. Sci. 31:542-562.

Michejda J, 1954. [Analiza stosunków ekologicznych źródeł i potoków Gór Stołowych]. [Article in Polish]. Prace Kom. Mat. przyr. PTPN 6:1-109.

Ministerstwo Środowiska, 2014. [Rozporządzenie Ministra Środowiska z dnia 6 października 2014 r. w sprawie ochrony gatunkowej zwierząt]. [Decree in Polish]. Dz.U. 2014, poz. 1348 .

Pachocka M, 2003. [Chruściki Królewskich Źródeł]. [Article in Polish]. Trichopteron 7:1-4.

Pietrzak L, 2000. [Próba wyznaczenia stref strumienia w krajobrazie pojeziernym w oparciu o faunę chruścików (Trichoptera)]. [Abstract in Polish]. In: B. Czeczuga and J.I. Rybak (eds.), Congress materials of 18th Congress of Polish Hydrobiologists, 4-8 September 2000, Białystok:204-205.

Pirinen P, Simola H, Aalto J, Kaukoranta J-P, Karlsson P, Ruuhela R, 2012. Climatological statistics of Finland 1981-2010. Reports 2012:1. Finnish Meteorological Institute, Helsinki.

Qu X, Wu N, Tang T, Cai Q, Park Y-S, 2010. Effects of heavy metals on benthic macroinvertebrate communities in high mountain streams. Ann. Limnol.-Int. J. Lim. 46:291-302.

Racięcka M, 1933. [Przyczynek do znajomości Chróścików (Trichoptera) ziem Polski]. [Article in Polish]. Pol. Pism. Entomol. 12:17-27.

Riedel W, 1966. [Chruściki (Trichoptera) potoków Bieszczad]. [Article in Polish]. Fragm. Faun. 13:51-112.

Riedel W, 1972. [Materiały do znajomości rozmieszczenia chruścików (Trichoptera) w Polsce, II]. [Article in Polish]. Fragm. Faun. 28:245-256.

Riedel W, 1978. [Chruściki (Trichoptera) Pienin]. [Article in Polish]. Fragm. Faun. 23:247-265.

Rychła A, Buczyńska E, 2013. Species richness and diversity of caddisflies (Trichoptera) in a selected area in mid-western Poland (Lubuskie Province). Annales Univ. Mariae CurieSkłodowska, sec. C 68:55-73.

Schindler H, 2004. [Bewertung der Auswirkungen von Umweltfaktoren auf die Struktur und Lebensgemeinschaften von Quellen in Rheinland-Pfalz]. [PhD Thesis in German]. Univ. of Koblenz and Landau, Landau in der Pfalz.

Sowa R, Szczęsny B, 1970. [Widelnice (Plecoptera) i chruściki (Trichoptera) Babiej Góry]. [Article in Polish]. Ochr. Przyr. 35:221-268.

Szczepański W, 2003. [Chruściki (Trichoptera) źródeł okolic Olsztyna]. [Master Thesis in Polish]. Univ. of Warmia and Mazury, Olsztyn.

Szczęsny B, 1975. Caddisflies (Trichoptera) of the Raba river. Acta Hydrobiol. 17:35-51. 
Szczęsny B, 1986. Caddisflies (Trichoptera) of running water in the polish North Carpathians. Acta Zool. Cracov. 29:501-586.

Szczęsny B, 1990. Benthic macroinvertebrates in acidified streams of the Świętokrzyski National Park (central Poland). Acta Hydrobiol. 32:155-169.

Szczucińska AM, 2009. [Wypływy wód podziemnych w Rynnie Gryżyńsko-Grabińskiej]. [Book in Polish]. Wydawnictwo Bogucki, Poznań.

Szczucińska AM, 2014. Spatial distribution and hydrochemistry of springs and seepage springs in the Lubuska Upland of western Poland. Hydrol. Res. 45:379-390.

Szczucińska AM, Siepak M, Marciniak M, Zioła-Frankowska A, 2010. Seasonal and spatial changes of metal concentrations in groundwater outflows from porous sediments in the Gryzyna - Grabin Tunnel Valley in western Poland. Environ. Earth. Sci. 61:921-930.

Thienemann A, 1924. [Hydrobiologische Untersuchungen an Quellen]. [Article in German]. Arch. Hydrobiol. 14:151-190.
Tomaszewski W, 1932. [Beitrag zur Kenntnis der Tierwelt Schlesischer Bergbäche]. [Article in German]. Abh. Naturf. Ges. Görlitz 31:1-80.

Tomaszewski C, 1965. [Katalog Fauny Polski. Chruściki (Trichoptera)]. [Book in Polish]. Państwowe Wydawnictwo Naukowe, Warszawa.

Veith M, 2006. [Chruściki (Trichoptera) środkowego odcinka rzeki Łupawy]. [Master Thesis in Polish]. Univ. of Warmia and Mazury, Olsztyn.

von Fumetti S, Nagel P, 2011. A first approach to faunistic crenon typology based on functional feeding groups. J. Limnol. 70:147-154.

Williams DD, Williams NE, Cao Y, 2000. Road salt contamination of groundwater in a major metropolitan area and development of a biological index to monitor its impact. Wat. Res. 34:127-138.

Zaćwilichowska K, 1964. [Chruściki (Trichoptera) potoku Wielka Puszcza]. [Article in Polish]. Acta Hydrobiol. 6:139-154. 